Новикова И.И., ${ }^{1,}$, Юрк Д.Е., ${ }^{1,3}$ Михеев В.Н. ${ }^{1}$, Сорокина А.В. ${ }^{1}$, Ивлева Г.П. ${ }^{1}$

${ }^{1}$ ФБУН «Новосибирский научно-исследовательский институт гигиены» Роспотребнадзора

${ }^{2}$ ФБОУ ВО «Новосибирский государственный медицинский университет» Минздрава России

зФГБНУ «Восточно-Сибирский институт медико-экологических исследований» (Ангарск)

\title{
Features of the efficiency indicators of children's health improvement in stationary recreation and health promotion organizations during the COVID-19 pandemic
}

\author{
Novikova I.I. ${ }^{1,2}$, Yurk D.E. ${ }^{1,3}$, Mikheev V.N. ${ }^{1}$, Sorokina A.V. ${ }^{1}$, Ivleva G.P. ${ }^{1}$ \\ ${ }^{1}$ Novosibirsk Research Institute of Hygiene \\ ${ }^{2}$ Novosibirsk State Medical University \\ ${ }^{3}$ East-Siberian Institute of Medical and Environmental Research (Angarsk)
}

\begin{abstract}
АННОТАЦИЯ
В в е д е н и е. Оздоровление детей в стационарных загородных организациях отдыха и оздоровления - одно из приоритетных направлений охраны здоровья детей и социальной политики государства. Введенный тотальный режим самоизоляции в весенний период 2020 г. в связи с пандемией COVID-19 и переход на дистанционную форму обучения внесли существенные коррективы в сложившиеся стереотипы режима дня и поведения детей, привели к сокращению времени пребывания на свежем воздухе, снижению их двигательной активности.

Ц е л ь и с с л е д в в н и я . Сравнительная оценка показателей эффективности оздоровления детей в пандемический (2020 г.) и неэпидемический (2018-2019 гг.) периоды в летних стационарных загородных организациях отдыха и оздоровления детей.

М а т е и а лы и м е т о д . Работа выполнялась в рамках реализации пилотного проекта «Оценка эффективности оздоровления» (2018-2020 гг.) на территории 15 субъектов Российской Федерации. Информация собиралась и анализировалась в программном средстве «Оценка организации оздоровления детей в стационарных загородных организациях отдыха и оздоровления», разработанном ФБУН «Новосибирский НИИ гигиены» Роспотребнадзора. Объектом исследования были дети в возрасте 7-17 лет ( $n=85666)$, отдыхавшие в летний период в 20182020 гг. в 134 стационарных организациях отдыха и оздоровления. Для определения эффективности оздоровления оценивались такие показатели, как длина и масса тела, жизненная емкость легких, кистевая сила рук и их динамика, за период оздоровительной смены. Оценка результатов проводилась в соответствии с МР 2.4.4.0127-18 «Методика оценки эффективности оздоровления в стационарных организациях отдыха и оздоровления детей».

Р е з у л ь т а т ы . Выявлено снижение удельного веса детей с высокой эффективностью оздоровления в 2020 г. в сравнении с 2018-2019 гг. за счет отсутствия положительной динамики показателей кистевой силы рук и жизненной емкости легких, а также негативной динамики индекса массы тела.

3 а к л ю ч е и е. Более низкие показатели эффективности оздоровления детей обусловлены выраженным снижением двигательной активности и времени пребывания на свежем воздухе в период, предшествующий летнему оздоровительному сезону 2020 г.
\end{abstract}

Ключевъе слова: оценка эффективности оздоровления, дети, индекс Кетле, функция внешнего дыхания, кистевая сила рук, пандемия, COVID-19.

Поступила 03.03.2021

Принята 15.03.2021

Автор, ответственный за переписку

Новикова Ирина Игоревна: ФБУН «Новосибирский научно-исследовательский институт гигиены» Роспотребнадзора. 630108, г. Новоси-

бирск, ул. Пархоменко, 7.

E-mail: novik_ir7o@rambler.ru
Received 03.03.2021

Accepted 15.03.2021

Corresponding author

Novikova Irina Igorevna: Novosibirsk Research Institute of Hygiene, 7, Parkhomenko str., Novosibirsk, 630108, Russia.

E-mail: novik_ir7o@rambler.ru 


\section{ABSTRACT}

In trod u cti o $\mathrm{n}$. Rehabilitation of children in stationary suburban recreation and health improvement organizations (camps) is one of the priority directions for children's health care and social policy of the state. The introduced total self-isolation regimen in the spring of 2020 due to the COVID-19 pandemic and the transition to distance education made significant adjustments to the prevailing stereotypes of the daily routine and behavior of children, led to a reduction in the time spent in the open air, a decrease in their physical activity.

A im of the resea r ch. Comparative evaluation of the efficiency indicators of children's health improvement in the pandemic (2020) and non-epidemic (2018-2019) periods in children's summer stationary suburban camps for recreation and health promotion.

Materials and methods. The study was carried out as a part of the pilot project implementation "Evaluation of the Health Improvement Efficiency" (2018-2020) on the territory of 15 constituent entities of the Russian Federation. The information was collected and analyzed using the software "Evaluation of the Organization of Children's Health Improvement in Stationary Suburban Recreation and Health Promotion Camps", developed by the Novosibirsk Research Institute of Hygiene of Federal Service for the Oversight of Consumer Protection and Welfare (Novosibirsk). The object of the study was children aged $7-17$ years $(n=85666)$ who had a rest in 134 stationary recreation and health improvement camps in the summer of 2018-2020. To determine the efficiency of recuperation, such indicators as the length and weight of the body, lung capacity, hand strength and their dynamics were assessed during the period of the health improving shift. Evaluation of the results was carried out in accordance with 2.4.4.0127-18 "Methodology for Evaluating the Efficiency of Health Improvement in Stationary Organizations for Recreation and Health Promotion of Children" guidelines.

Results. It was revealed a decrease in the proportion of children with a high efficiency of health improvement in 2020 in comparison with 2018-2019 due to the lack of positive dynamics of hand strength and vital capacity of the lungs indicators, as well as negative dynamics of body mass index.

Conclusion. The lower indicators of the efficiency of children's health improvement are due to a considerable decrease in physical activity and the time spent in the open air in the period preceding the summer health-improving season of 2020.

Keywords: evaluation of health improvement efficiency, children, Quetelet Index, pulmonary function, hand strength, pandemic, COVID-19.

\section{$\mathrm{BBE}$ Д $\mathrm{H} \amalg \mathbb{E}$}

Укрепление и охрана здоровья детей и молодежи является приоритетным направлением национальной политики государства [1-3]. Организация оздоровления предполагает создание условий, направленных на укрепление здоровья детей [4-9], расширение их адаптационных возможностей $[10,11]$. Введенный тотальный режим самоизоляции в весенний период 2020 г. в связи c пандемией COVID-19 и переход на дистанционную форму обучения внесли существенные коррективы в сложившиеся стереотипы режима дня и поведения детей в четвертой учебной четверти 2019/20 учебного года, привели к сокращению времени пребывания детей на свежем воздухе, снижению их двигательной активности [12-17], в связи с чем актуализировался научный интерес к изучению особенностей физиологических реакций детей на отдых и оздоровление в летний сезон 2020 г. в сравнении с обычными условиями.

\section{ЦЕЛЬ ИССЛЕДОВАНИЯ}

Сравнительная оценка показателей эффективности оздоровления детей в пандемический и неэпидемический периоды в летних стационар-

\section{INTRODUCTION}

Protection and promotion of children's and youth's health is a priority direction of the state national policy [1-3]. The organization of health improvement presupposes the creation of conditions aimed at children's health promotion [4-9], and expanding their adaptive capabilities $[10,11]$. The introduced total self-isolation regime in the spring of 2020 in connection with the COVID-19 pandemic and the transition to distance education made significant adjustments to the prevailing stereotypes of the daily routine and behavior of children in the fourth school term of the 2019/20 academic year, led to a reduction in time spent by children in the open air, a decrease in their physical activity [12-17]. For this reason the scientific interest in the study of the peculiarities of children's physiological reactions to rest and health improvement in the summer season of 2020 in comparison with usual conditions has been actualized.

\section{AIM OF THE RESEARCH}

Comparative evaluation of the children's health improvement efficiency indicators in pandemic and non-epidemic periods in summer stationary subur- 
ных загородных организациях отдыха и оздоровления детей.

\section{МАТЕРИАЛЫ И МЕТОДЫ}

В рамках выполнения мероприятий по реализации указа президента Российской Федерации от 29.05.2017 № 240 «Об объявлении в Российской Федерации Десятилетия детства», национального проекта «Демография» в части решения задач по формированию у детей здорового образа жизни и здорового питания в 20182020 гг. на территории 15 субъектов Российской Федерации реализовывался пилотный проект «Оценка эффективности оздоровления». Стационарные загородные организации отдыха и оздоровления детей в летние сезоны 2018-2020 гг. оценивали эффективность оздоровления детей в программном средстве «Оценка организации оздоровления детей в стационарных загородных организациях отдыха и оздоровления», специально разработанном для этих целей ФБУН «Новосибирский НИИ гигиены» Роспотребнадзоpa [18].

Объект исследования - дети в возрасте 7-17 лет, отдыхавшие в 134 стационарных организациях отдыха и оздоровления. С помощью вычислительного ядра программного обеспечения был произведен анализ материала, полученного в ходе летней оздоровительной кампании.

Результаты эффективности оздоровления по итогам летнего оздоровительного сезона 2020 г. сравнивались с показателями неэпидемического периода (2018-2019 гг.). Оценивались следующие показатели: длина и масса тела, жизненная емкость легких, кистевая сила рук в динамике за период оздоровительной смены $(n=85666)$. Физическое развитие детей оценивалось с использованием индекса массы тела. Оценка результатов исследований проводилась в соответствии с «Методикой оценки эффективности оздоровления в стационарных организациях отдыха и оздоровления детей» [7].

Статистическая обработка полученных результатов проведена с использованием программного пакета STATISTICA 10. Корректировка, систематизация исходной информации и визуализация полученных результатов осуществлялись в электронных таблицах Microsoft Office Excel 2016.

\section{РЕЗУЛЬТАТЫ И ОБСУЯКДЕНИЕ}

В условиях стационарных загородных организаций отдыха и оздоровления детей природные факторы, рациональный режим дня, здоро- ban camps for recreation and health improvement of children.

\section{MATERIALS AND METHODS}

As part of the implementation of measures to realize the decree of the Russian Federation President of 05/29/2017 No. 240 "On the Announcement of the Decade of Childhood in the Russian Federation", the National Demography Project in terms of solving on the territory of 15 constituent entities of the Russian Federation, a pilot project "Evaluation of the Efficiency of Health Improvement" was being implemented. Stationary out-of-town organizations for recreation and health improvement of children in the summer seasons of 2018-2020 assessed the efficiency of children's health improvement using the software "Evaluation of the Organization of Children's Health Improvement in Stationary Suburban Recreation and Health Promotion Camps", developed specifically for these purposes by the Novosibirsk Research Institute of Hygiene (Novosibirsk) [18].

The object of the study was children aged 7-17 years, who were resting in 134 stationary recreation and health improvement camps. With the help of the software computing core, the analysis of the material obtained during the summer health promotion campaign was made.

The results concerning the health improvement efficiency according to the follow-ups of the summer health improvement season in 2020 were compared with the indicators of the non-epidemic period (2018-2019). The following indicators were assessed: body length and weight, lung capacity, hand strength in dynamics during the health-improving shift $(n=85666)$. The physical development of children was assessed using the body mass index. The evaluation of the research results was carried out in accordance with the Methodology for Evaluating the Efficiency of Health Improvement in Stationary Children's Organizations for Recreation and Health Promotion [7].

Statistical processing of the obtained results was carried out using the STATISTICA 10 software package. Correction, systematization of the initial information and visualization of the results obtained were carried out in Microsoft Office Excel 2016 spreadsheets.

\section{RESULTS AND DISCUSSION}

In the conditions of stationary suburban camps for recreation and health improvement of children, natural factors, a rational daily routine, healthy nu- 
вое питание, максимальное пребывание на свежем воздухе, а также закаливающие процедуры являются основными средствами оздоровления. Оценка показателей эффективности оздоровления проводилась по результатам антропометрических и физиометрических измерений в начале смены и по ее окончании.

Результаты сравнительной оценки исходных показателей, антропо- и физиометрии, а также показателей физического развития в сравниваемые периоды статистически значимых различий не выявили ( $p \geq 0.05)$. Так, среди отдохнувших в 2020 г. удельный вес детей с гармоничным физическим развитием составил $73.5 \%$ (против $74.4 \%$ в 2018-2019 гг.), с дефицитом массы тела - 11.4\% (в 2018-2019 гг. - 8.5\%), с избытком массы тела - 15.1\% (в 2018-2019 гг. - 17.1\%).

Удельный вес детей с высокой эффективностью оздоровления в 2020 г. в сравнении с неэпидемическим периодом был существенно ниже и составил 71.6 \% против 86.9 \% в 20182019 гг. (рис. 1). Низкая эффективность оздоровления отмечалась у 22.7 \% отдохнувших детей (против показателя неэпидемического периода - $9.5 \%)$. Эффективность оздоровления отсутствовала у 5.7 \% отдохнувших в 2020 г. детей (в неэпидемический период - $3.6 \%$ ). Основная причина отсутствия у отдохнувших детей оздоровительного эффекта в 2020 г. заключалась в отсутствии в 77.9 \% случаев положительной динамики функции внешнего дыхания и кистевой силы рук, а также негативной динамики индекса массы тела за оздоровительную смену. Второе ранговое место занимало отсутствие положительной динамики функции внешнего дыхания и кистевой силы рук (20.6 \%), третье ранговое место - прирост мас- trition, maximal open air exposure, as well as hardening procedures are the main means of recovery. Evaluation of health improvement efficiency indicators was carried out according to the results of anthropometric and physiometric measurements at the beginning and end of the shift.

The results of a comparative evaluation for baseline indicators, anthropo- and physiometry, as well as indicators of physical development in the compared periods did not reveal statistically significant differences ( $p \geq 0.05$ ). Thus, among those rested in 2020, the proportion of children with harmonious physical development was $73.5 \%$ (vs. $74.4 \%$ in $2018-$ 2019), with a body weight deficit $-11.4 \%$ (in $2018-$ $2019-8.5 \%$ ), with overweight $-\mathbf{1 5 . 1 \%}$ (in 2018$2019-17.1 \%)$.

The proportion of children with a high efficiency of recovery in 2020 compared with the nonepidemic period was significantly lower and amounted to $71.6 \%$ vs. $86.9 \%$ in $2018-2019$ (Fig. 1). Low efficiency of health improvement was noted in $22.7 \%$ of rested children (vs. the non-epidemic period indicator - 9.5\%). The efficiency of health improvement was lacking in $5.7 \%$ of children rested in 2020 (in the non-epidemic period $3.6 \%)$. The main reason for the absence of a healthimproving effect in rested children in 2020 was the lack of positive dynamics in the function of external respiration and hand strength in $77.9 \%$ of cases, as well as the negative dynamics of body mass index over the wellness shift. The second rank place was occupied by the lack of positive dynamics in the pulmonary function and hand strength (20.6\%), the third rank place was an increase in body weight in children with overweight $(1.5 \%$ of children) (Fig. 2).

In the methodological aspect, the structure of the health improvement efficiency indicator was ba-

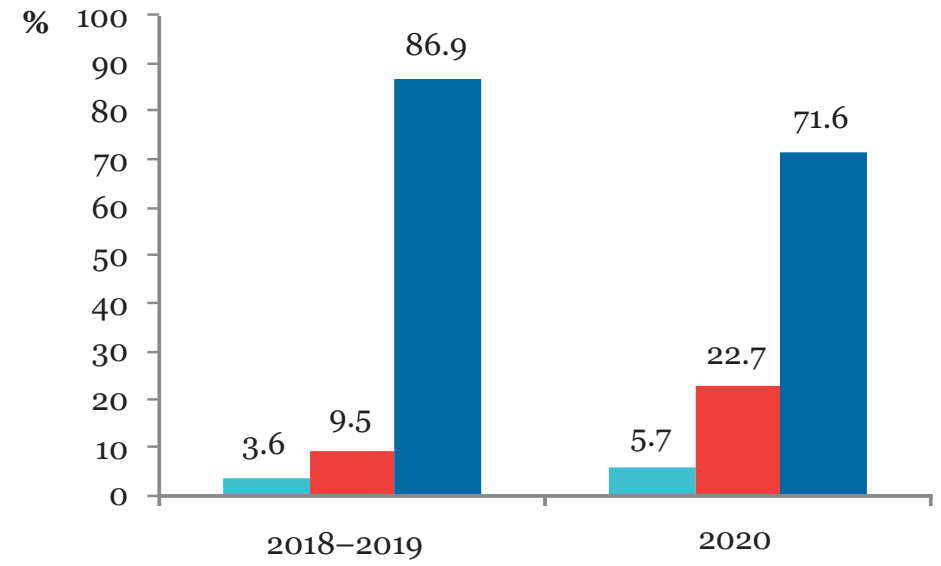

Отсутствие эффективности Failure response

- Низкая эффективность Low efficiency

- Высокая эффективность High efficiency

Рис. 1. Распределение детей в группы по эффективности оздоровления

Fig. 1. Distribution of children into groups according to the health improvement efficiency 
сы тела у детей с избытком массы тела (1.5 \% детей) (рис. 2).

В методологическом аспекте структура показателя эффективности оздоровления в своей основе определялась количеством набранных баллов по динамике показателей длины и массы тела, кистевой силы рук и жизненной емкости легких за смену [7]. Если суммарно (по измерениям роста, массы тела, мышечной силы и функции внешнего дыхания) ребенок набрал за оздоровительную смену 12-16 баллов и выше, эффективность оздоровления считалась высокой; 6-11 баллов - низкой; менее 6 баллов - оздоровительный эффект отсутствовал.

Сравнительная характеристика суммарного показателя и составляющих его компонентов показала, что эффективность оздоровления в летний оздоровительный сезон 2020 г. была существенно ниже по сравнению с 2018-2019 г., причем данная ситуация отмечалась как в группе детей с нормальной массой тела, так и с избытком и дефицитом массы тела (рис. $3, \mathrm{~A})$.

Различия суммарного показателя эффективности оздоровления детей в 2020 г. в сравнении с неэпидемическим периодом 2018-2019 гг. были обусловлены преимущественно недобором детьми баллов в 2020 г. по таким компонентам суммарного показателя эффективности оздоровления, как жизненная емкость легких и кистевая сила рук (рис. 3, В, С и 4).

В индикаторной группе детей - дети с дефицитом массы тела, стабильно демонстрировавшие наиболее высокие величины показателей, характеризующих суммарно эффективность оздоровления (изменения массы тела, sically determined by the number of points scored on the dynamics of body length and weight, hand strength and lung capacity over a shift [7]. If in total (in terms of measurements of height, body weight, hand strength and pulmonary function) a child scored 12-16 points and higher over a health-improving shift, the efficiency of health improvement was considered high; 6-11 points - low; less than 6 points - without health-improving effect.

Comparative characteristics of the total indicator and its constituent components showed that the health improvement efficiency in the summer healthimproving season of 2020 was significantly lower compared to 2018-2019, and this situation was observed both in the group of children with normal body weight and with overweight and underweight (Fig. 3, A).

Differences in the total indicator of the children's health improvement efficiency in 2020 in comparison with the non-epidemic period of 20182019 were mainly due to the shortage of points gained by children in 2020 for such components of the health-improving efficiency's indicator as the lung capacity and hand strength (Fig. 3, B, C and 4).

In the indicator group of children - underweight children, who consistently demonstrated the highest indicators characterizing the total health improvement efficiency (changes in body weight, body length, pulmonary function and hand strength) the most pronounced differences between the indicators of 2020 and 2018-2019 were noted ( $p \leq 0.05$ ). Differences were revealed both in the total indicator of the health improvement efficiency (14.06 points vs. 16.24 points) and in its key components - lung capacity (3.32 points vs. 3.94 points), hand strength (3.39 points vs. 4.44 points) (see Fig. 3).

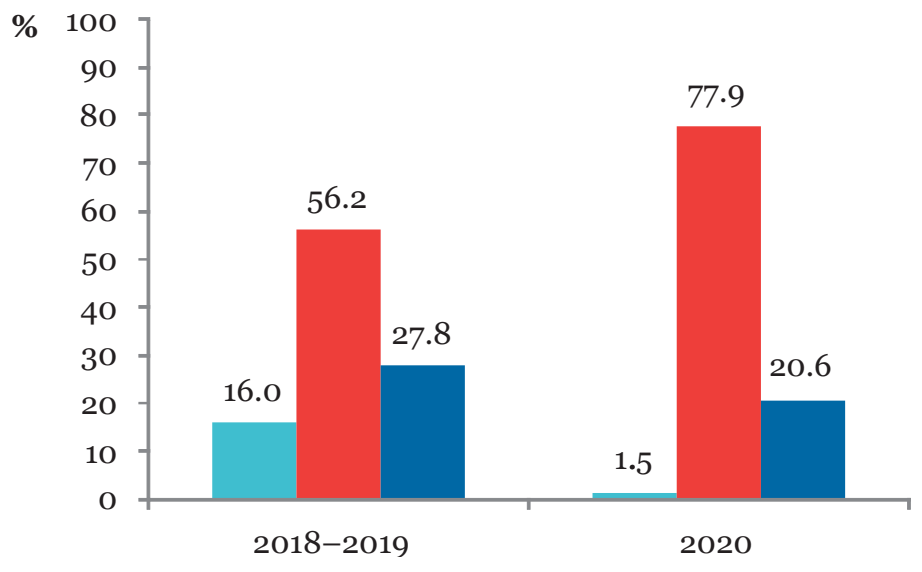

Негативная динамика ИМТ Negative dynamics of BMI

О Отсутствие положительной динамики функции внешнего дыхания и кистевой силы рук и негативная динамика ИМТ Lack of positive dynamics of the pulmonary function and hand strength function and negative dynamics of BMI

— Отсутствие положительной динамики функции внешнего дыхания, кистевой силы рук

Lack of positive dynamics of the pulmonary function and hand strength function

Рис. 2. Структура причин отнесения детей к группе с отсутствием оздоровительного эффекта (ИМТ - индекс массы тела)

Fig. 2. The structure of the reasons for attributing children to the group with the lack of health-improving effect (BMI - body mass index) 


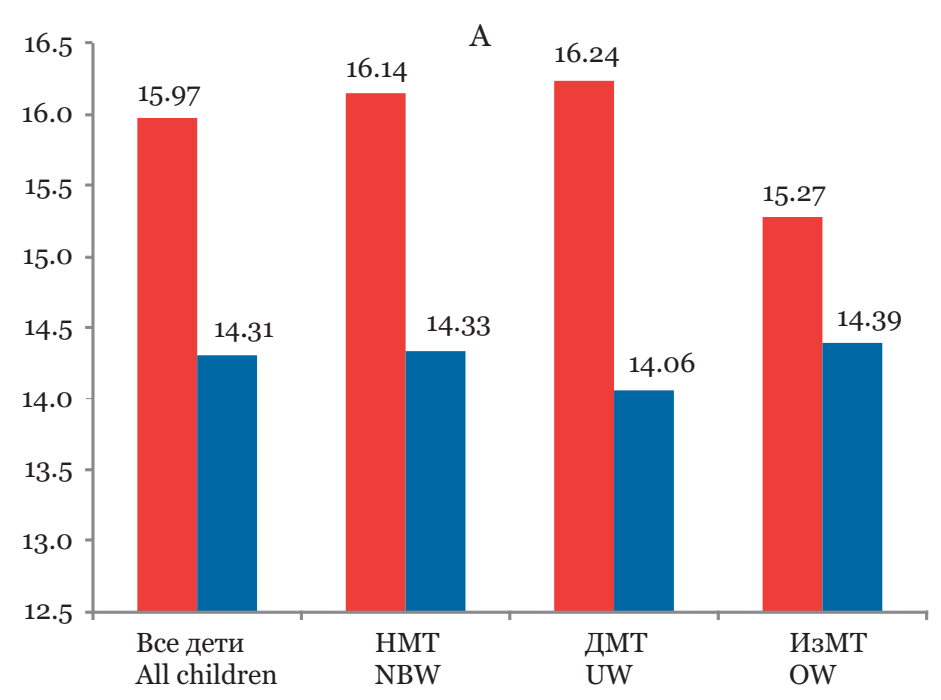

2018-2019

2020

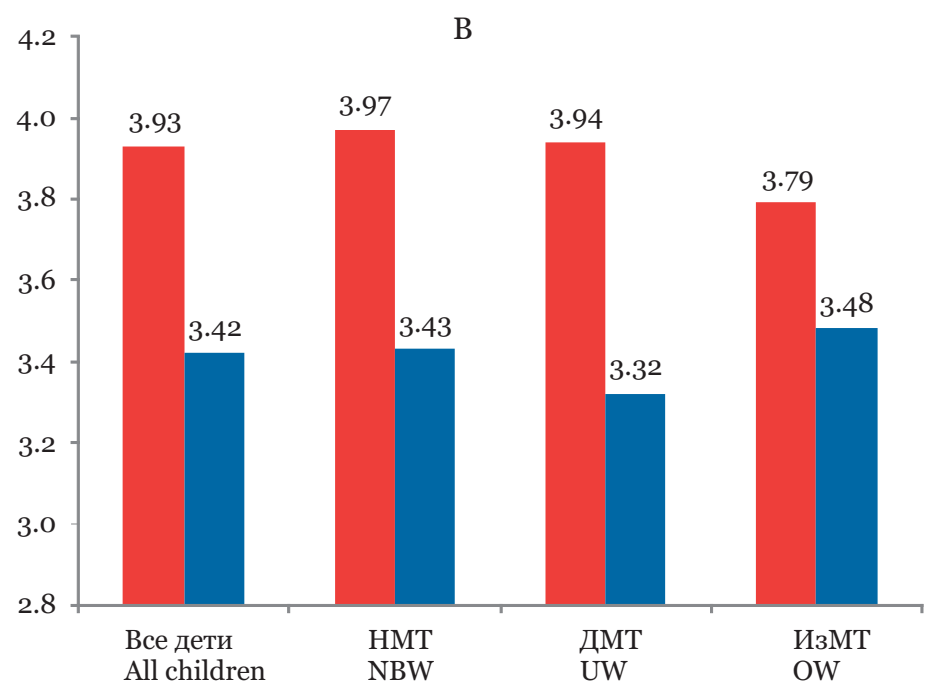

$\mathrm{C}$

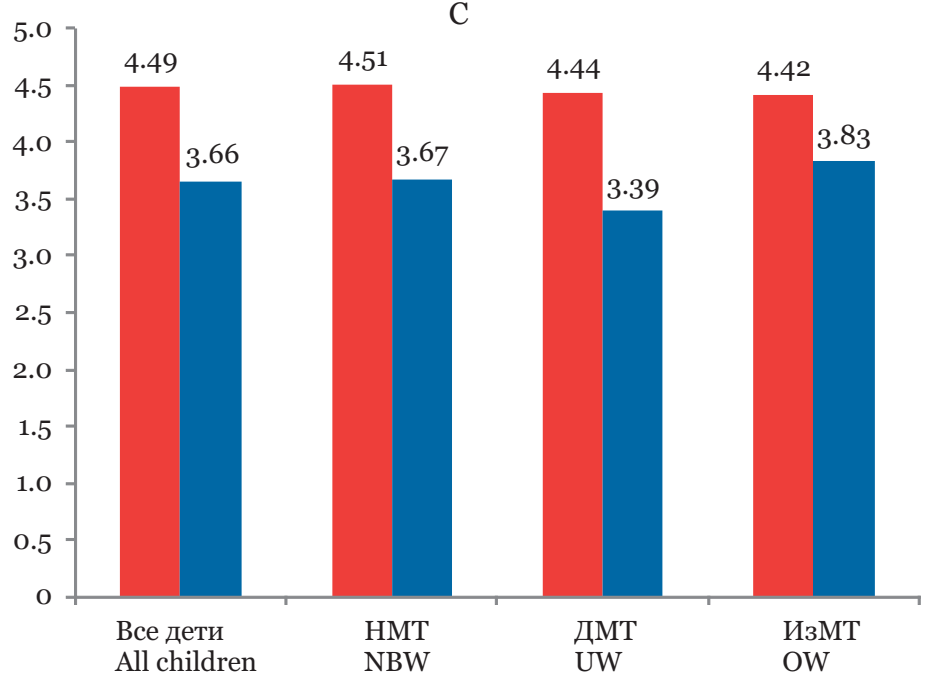

Рис. 3. Сравнительная характеристика средних показателей, демонстрирующая эффективность оздоровления в целом по всей группе детей (баллы) (НМТ - нормальная масса тела; ДМТ - дефицит массы тела; ИзМТ избыток массы тела): А - суммарный показатель; В - жизненная емкость легких; С - кистевая сила рук

Fig. 3. Comparative characteristics of the average indicators demonstrating the health improvement efficiency in general for the entire group of children (points) (NBW - normal body weight; UW - underweight; OW - overweight): A - total indicator; B - lung capacity; C - hand strength 


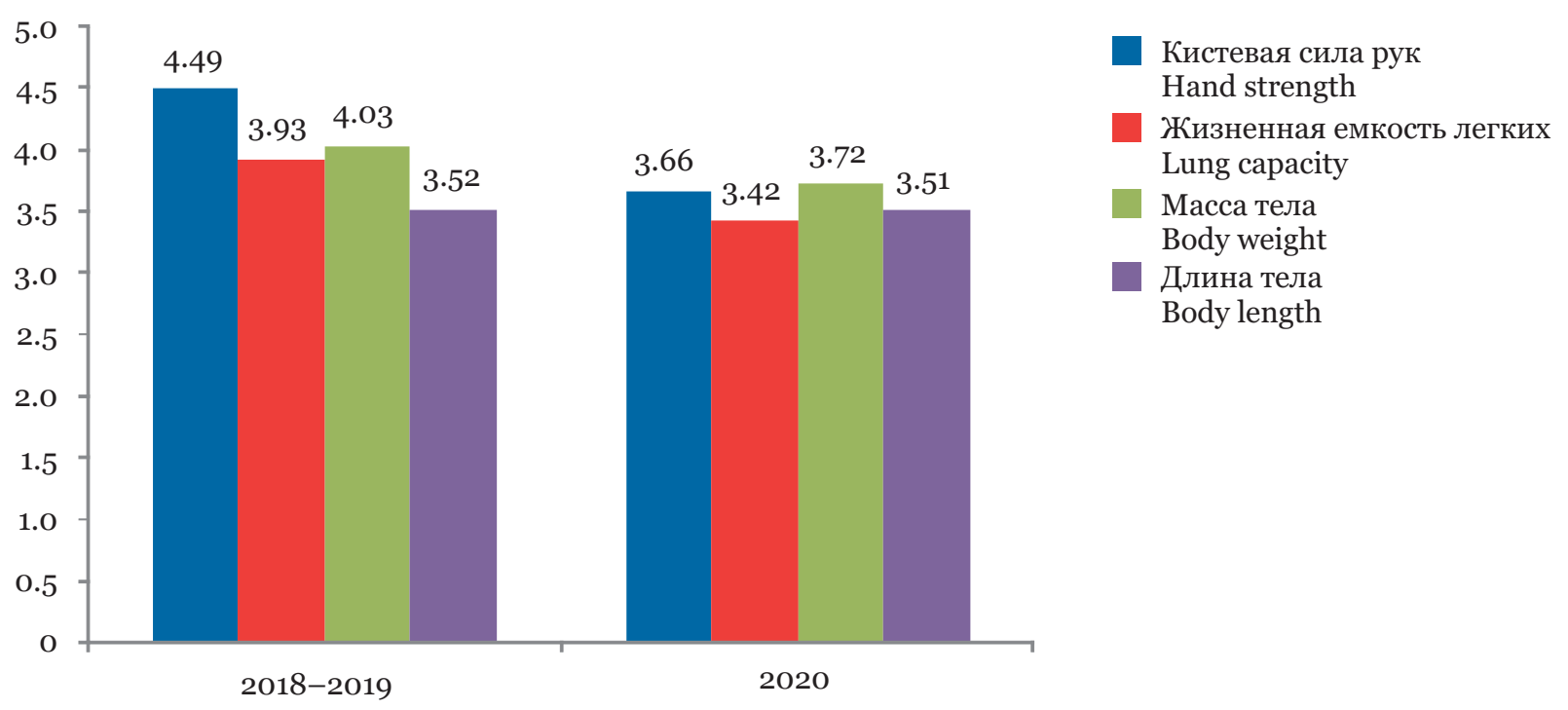

Рис. 4. Показатели эффективности оздоровления (баллы)

Fig. 4. Health improvement indicators (points)

длины тела, функции внешнего дыхания и кистевой силы) - отмечались наиболее выраженные различия показателей 2020 г. и 20182019 гг. ( $p \leq 0.05)$. Различия выявлены как по суммарному показателю эффективности оздоровления (14.06 балла против 16.24 балла), так и по его ключевым составляющим - жизненной емкости легких (3.32 балла против 3.94 балла), кистевой силе рук (3.39 балла против 4.44 балла) (см. рис. 3).

Наименьшие различия в показателях эффективности оздоровления 2020 г. и 20182019 гг. отмечались в группе детей, имевших избыточную массу тела. Суммарный показатель эффективности оздоровления в 2020 г. составил 14.39 балла против 15.27 балла в неэпидемический период. Показатель жизненной емкости легких - 3.48 балла против 3.79 балла соответственно, кистевой силы рук -3.83 балла против 4.42 балла соответственно (см. рис. 3). В сравнении с 2018-2019 гг. средние показатели в баллах по отдельным компонентам суммарного показателя эффективности оздоровления в 2020 г. составили по кистевой силе рук 81.6 \% (ниже показателя 2018-2019 гг. на 18.37 \%), жизненной емкости легких - 87.0 \% (ниже на 12.97 \%), массы тела - 92.2 \% (ниже на $7.81 \%$ ), длины тела $98.4 \%$ (ниже на $0.16 \%$ ).

Показатели вариабельности результатов балльной оценки изменений функции внешнего дыхания и кистевой силы рук у детей также демонстрируют существенное отличие результатов 2020 г. и 2018-2019 гг. (рис. 5).
The smallest differences in the health improvement efficiency indicators in 2020 and 2018-2019 were noted in the group of overweight children. The total indicator of the health improvement efficiency in 2020 was 14.39 points vs. 15.27 points in the nonepidemic period. The indicator of the lung capacity was 3.48 points vs. 3.79 points respectively, and the hand strength was 3.83 points vs. 4.42 points respectively (see Fig. 3). Compared to 2018-2019, the average score for individual components of the health improvement efficiency total indicator in 2020 amounted to $81.6 \%$ in hand strength $(18.37 \%$ lower than in 2018-2019), lung capacity - 87.0\% (12.97\% lower), body weight $-92.2 \%$ (7.81\% lower), body length $-98.4 \%$ (0.16\% lower).

Indicators of variability of the results in the pulmonary function and hand strength in children also demonstrate a significant difference between the results of 2020 and 2018-2019 (Fig. 5).

Thus, the children's health improvement efficiency in the summer health promotion season of 2020 in the context of the COVID-19 pandemic was characterized by: a decrease in the proportion of children with high health improvement efficiency and average indicators of the total score which reflects the efficiency of health improvement, the values of individual components of the total health improvement indicator (primarily hand strength, lung capacity, and body weight); the greatest differences in the total health improvement indicators in underweight children - in the pandemic this group of children performed the function of an indicator group. This can be regarded as one of the latent consequences of the pandemic. 
A

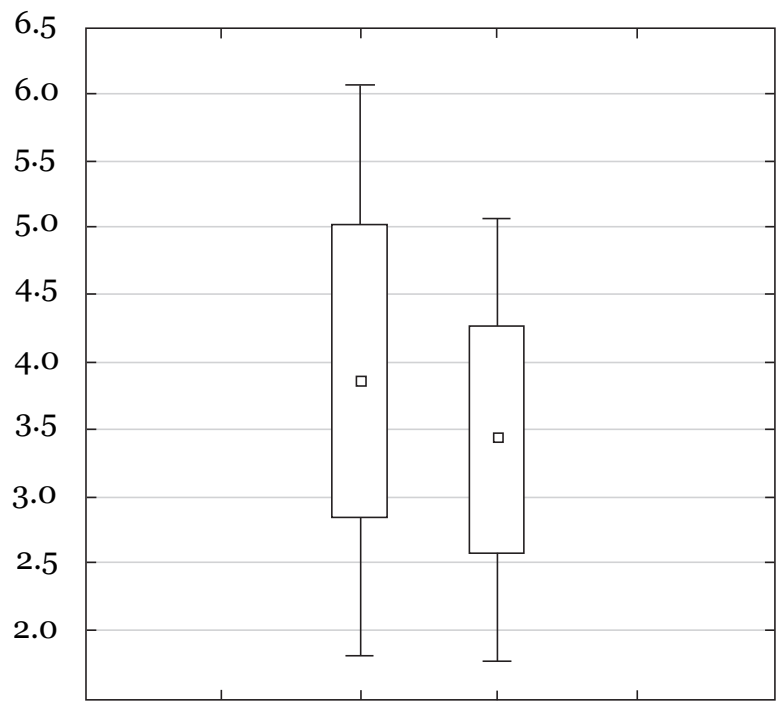

Среднее / Mean

Среднее \pm стандартное отклонение

Mean \pm standard deviation

I Среднее $\pm 1.96 \times$ стандартное отклонение

Mean $\pm 1.96 \times$ standard deviation
B

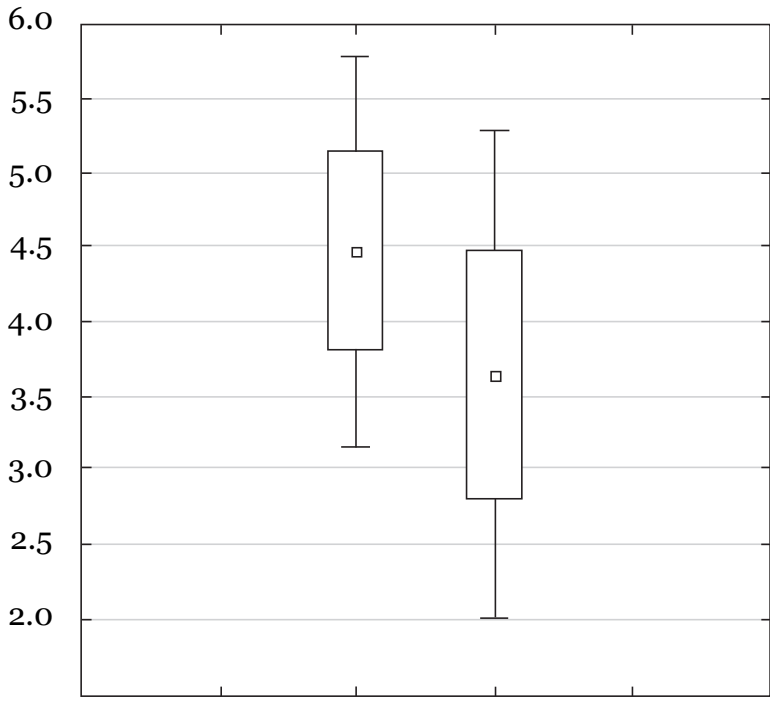

Среднее / Mean

$\square$ Среднее \pm стандартное отклонение

Mean \pm standard deviation

工 Среднее $\pm 1.96 \times$ стандартное отклонение

- Mean $\pm 1.96 \times$ standard deviation

Рис. 5. Сравнительная характеристика показателей вариабельности результатов балльной оценки изменений функции внешнего дыхания (А) и кистевой силы у детей (B)

Fig. 5. Comparative characteristics of variability indicators of the results in the pulmonary function (A) and hand strength (B) in children

Таким образом, эффективность оздоровления детей в летний оздоровительный сезон 2020 г. в условиях пандемии COVID-19 характеризовалась: снижением удельного веса детей с высокой эффективностью оздоровления и средних показателей суммарного количества баллов, характеризующих эффективность оздоровления, значений отдельных компонентов суммарного показателя эффективности оздоровления (прежде всего кистевой силы рук, жизненной емкости легких, а также массы тела); наибольшими различиями в суммарных показателях эффективности оздоровления у детей с дефицитом массы тела - данная группа детей в условиях пандемии выполнила функцию индикаторной группы. Это может расцениваться как один из результатов скрытых последствий пандемии.

\section{ЗАКЛЮЧЕНИЕ}

В результате проведенного исследования были установлены особенности показателей, характеризующих эффективность летнего оздоровления детей в пандемический период, а именно: более низкие значения за оздоровительную смену физиометрических показателей, обусловленные выраженным снижением двигательной ак-

\section{CONCLUSION}

As a result of the study, the features of the indicators characterizing the children's summer health improvement efficiency in the pandemic recuperative summer season were established, namely: the lower physiometric indicators over the recreation shift, due to the pronounced decrease in motor activity and the time spent in the open air as compared to the conditions of health improvement in the period preceding the summer recuperative season of 2020, and, accordingly, a longer adaptation to the daily regimen in the health improvement camps.

Conflict of interest. The authors declare no conflict of interest.

тивности и времени пребывания на свежем воздухе по сравнению с условиями оздоровления в период, предшествующий летнему оздоровительному сезону 2020 г., и соответственно более длительным адаптационным периодом к режиму дня в оздоровительной организации.

Конфликт интересов. Авторы заявляют об отсутствии конфликта интересов. 


\section{СПИСОК ЛИТЕРАТУРЫ}

1. Бородина И.А. Организация отдыха и оздоровления детей в условиях загородного лагеря // Уральские каникулы. Здоровье. Познание. Отдых. Актуальные проблемы летней оздоровительной кампании для детей и подростков: Материалы Межрегиональной науч.-практ. конф. (Екатеринбург, 4 апр. 2017 г.). Екатеринбург, 2017. С. 13-16.

2. Валеева Г.Х. Организация летнего отдыха, досуга и оздоровления детей // Актуальные направления научных исследований: перспективы развития: Материалы V Междунар. науч.-практ. конф. (Чебоксары, 23 апр. 2018 г.). Чебоксары: Интерактив плюс, 2018. С. 60-62.

3. Кондратьев Э.В. Особенности отдыха и оздоровления детей в условиях Крайнего Севера: по опыту Республики Саха (Якутия) // Детский отдых 2017: Сб. материалов по итогам XI Междунар. конгресса лагерей и III Междунар. конф. (Сочи (Роза Хутор), 9-13 окт. 2017 г.). М., 2017. С. 45-49.

4. Борисова T.С. Медико-гигиенические аспекты организации и проведения летней оздоровительной работы среди детей и подростков: учеб.-метод. пособие. Минск: БГМУ, 2019. 76 с.

5. Зайцева T.А., Редько О.А. Об организации и проведении летней оздоровительной кампании в Хабаровском крае // Российская гигиена - развивая традиции, устремляемся в будущее: Материалы XII Всерос. съезда гигиенистов и санитарных врачей (Москва, 17-18 ноября 2017 г.). М., 2017. Т. 1. C. 462-466.

6. Кучма В.Р. 2018-2027 годы - десятилетие детства в России: цели, задачи и ожидаемые результаты в сфере здоровьесбережения обучающихся // Вопр. школьной и университетской медицины и здоровья. 2017. № 3. С. 4-14.

7. Методика оценки эффективности оздоровления в стационарных организациях отдыха и оздоровления детей: Метод. рекомендации МР 2.4.4.0127-18. М.: Федеральная служба по надзору в сфере защиты прав потребителей и благополучия человека, 2019. 24 c.

8. Сладков Г.Д., Фодоря А.Ю. Прогноз предпочтений родителей по выбору видов детского отдыха на летнюю кампанию 2017 года // Профессиональный проект: идеи, технологии, результаты. 2017. № 1 (26). С. 78-88.

9. Сладков Г.Д. Использование показателя оздоровительного эффекта в оценке качества летнего отдыха и оздоровления детей (по опыту ГАУК «МОСГОРТУР») // Детский отдых 2017: Сб. материалов по итогам XI Междунар. конгресса лагерей и III Междунар. конф. (Сочи (Роза Хутор), 9-13 окт. 2017 г.). М., 2017. С. 127-130.

10. Дмитриева О.В., Моисеенко В.П. Проблемы оценки эффективности оздоровления детей в загородных стационарных учреждениях отдыха // Инновации в науке и практике: Сб. статей по материалам IX междунар. науч.-практ. конф. (Барнаул, 23 июня 2018 г.). Уфа: Дендра, 2018. С. 129-132.

11. Новикова И.И., Ерофеев Ю.В., Гришков Д.А. и др. Актуальность научной проработки организации эффективного оздоровления детей в стационарных

\section{REFERENCES}

1. Borodina I.A. (2017). Organization of recreation and health improvement for children in a country camp (pp. 13-16). In Ural holidays. Health. Cognition. Relaxation. Actual problems of the summer health campaign for children and adolescents: Materials of the Interregional Scientific-Practical Conf. Yekaterinburg 6. In Russ.

2. Valeeva G.Kh. (2018). Organization of summer recreation, leisure time and health improvement for children (pp. 60-62). In Actual directions of scientific research: development prospects: Materials of the V International Scientific-Practical Conf. Cheboksary. In Russ.

3. Kondratiev E.V. (2017). Features of recreation and health improvement of children in the Far North: the Republic of Sakha experience (Yakutia) (pp. 45-49). In Children's rest 2017: Collection of materials on the results of the XI Intern. Congress of camps and the III Intern. conf. (Sochi (Rosa Khutor), Oct. 9-13, 2017). Moscow. In Russ.

4. Borisova T.S. (2019). Medical and Hygienic Aspects of Organization and Conducting Summer Health Improvement Work among Children and Adolescents: Study Guide. Minsk, 76 p. In Russ.

5. Zaytseva T.A., Redko O.A. (2017). On the organization and conducting of the summer health campaign in the Khabarovsk Territory (pp. 462-466). In Russian hygiene - developing traditions, we rush into the future: Materials of the XII All-Russian congress of hygienists and sanitary doctors. Moscow, 1. In Russ.

6. Kuchma V.R. (2017). 2018-2027 - a decade of childhood in Russia: goals, objectives and expected results in the sphere of health saving of students. Problems of School and University Medicine and Health, 3, 4-14.

7. Methodology for Assessing the Efficiency of Health Improvement in Stationary Camps for Recreation and Health Promotion of Children. Guidelines 2.4.4.012718. Moscow: Federal Service for Surveillance on Consumer Rights Protection and Human Wellbeing, 2019, 24 p. In Russ.

8. Sladkov G.D., Fodorya A.Yu. (2017). The forecast of parents' choices for children's rest during summer campaign of 2017. Professional Project: Ideas, Technologies, Results, 1 (26), 78-88.

9. Sladkov G.D. (2017). Using the indicator of health-improving effect in assessing the quality of summer recreation and health improvement of children (according to the experience of the Moscow Agency for Recreation and Tourism) (pp. 127-130). In Children's rest 2017: Collection of materials on the results of the XI Intern. Congress of camps and the III Intern. conf. (Sochi (Rosa Khutor), Oct. 9-13, 2017), Moscow. In Russ.

10. Dmitrieva O.V., Moiseenko V.P. (2018). Problems of assessing the efficiency of children's health improvement in country stationary recreation camps (pp. 129132). In Innovations in science and practice: Collection of articles based on the materials of the IX Intern. scientific-practical conf. Ufa. In Russ.

11. Novikova I.I., Erofeev Yu.V., Grishkov D.A. et al. (2015). Relevance of scientific study of the organiza- 
загородных лагерях // Наука о человеке: гуманитарные исследования. 2015. № 4 (22). С. 126-129.

12. Флянку И.П., Новикова И.И., Ерофеев Ю.В., Истомина А., Булацева М.Б. Проблема гиподинамии у школьников и организация работы по восполнению дефицита двигательной активности // Актуальные вопросы гигиены, профпатологии и медицинской реабилитации: Сб. статей Всерос. науч.практ. конф. с междунар. участием (Новосибирск, 27-28 окт. 2016 г.). Новосибирск: НГМУ, 2016. C. $152-159$.

13. Кучма B.Р., Седова А.С., Степанова М.И. и др. Особенности жизнедеятельности и самочувствия детей и подростков, дистанционно обучающихся во время эпидемии новой коронавирусной инфекции (COVID-19) // Вопр. школьной и университетской медицины и здоровья. 2020. № 2. С. 4-23.

14. Корытова Г.С. Аутоагрессивное поведение обучающихся в период пандемии коронавирусной инфекции и самоизоляции // Академ. журн. Западной Сибири. 2020. Т. 16, № 3 (86). С. 26-28.

15. Шурыгина В.В., Костылев Д.В., Костылева Л.Н., Решетник А.С., Рахматуллина Э.А. Изучение регулярной физической активности в период пандемии // Уч. зап. университета им. П.Ф. Лесгафта. 2020. № 11 (189). C. 578-581.

16. Милушкина О.Ю., Попов В.И., Скоблина Н.А., Маркелова С.В., Соколова Н.В. Использование электронных устройств участниками образовательного процесса при традиционной и дистанционной формах обучения // Вестн. РГМУ. 2020. № 3. С. 85-91.

17. Заболотских Н.В., Выродова Е.Ю., Дорошева А.О. и др. Влияние дистанционного обучения на психоэмоциональное состояние школьников г. Краснодара // Кубанский науч. мед. вестн. 2020. Т. 27, № 6. С. $109-122$.

18. Оценка эффективности и организации оздоровления детей: программа для ЭВМ; правообладатель ФБУН «Новосибирский НИИ гигиены» Роспотребнадзора: Свидетельство RU 2019665484. Номер заявки: 2019664446. Дата публикации 22.11.2019. URL: http://www.niig. su/images/documents/rezultaty-intellektualnojdeyatelnosti/2019/Gos-reg-programmy-dlya-EVM/ Gos-reg-programmy-dlya-EVMBD_2019665484.pdf. Дата обращения: 07.04.2021.

\section{СВЕДЕНИЯ ОБ АВТОРАХ}

Новикова Ирина Игоревна - д-р мед. наук, директор ФБУН «Новосибирский научноисследовательский институт гигиены» Роспотребнадзора; профессор кафедры гигиены и экологии ФГБОУ ВО «Новосибирский государственный медицинский университет» Минздрава России.

Юрк Дмитрий Евгеньевич - младший научный сотрудник ФБУН «Новосибирский научноисследовательский институт гигиены» Роспотребнадзора; аспирант ФГБНУ «Восточно-Сибирский институт медико-экологических исследований» (Ангарск).

Михеев Валерий Николаевич - канд. мед. наук, заведующий отделом гигиенических исследований с лабораторией физических факторов ФБУН «Новосибирский научно-исследовательский институт гигиены» Роспотребнадзора. tion of effective improvement in children's camps. The Science of Person: Humanitarian Researches, 4 (22), 126-129.

12. Flyanku I.P., Novikova I.I., Erofeev Yu.V., Istomina A., Bulatseva M.B. (2016). The problem of physical inactivity in schoolchildren and the organization of work to compensate for the deficit of motor activity (pp. 152159). In Topical issues of hygiene, occupational pathology and medical rehabilitation: Collection of articles of the All-Russian scientific-practical conf. with int. participation. Novosibirsk. In Russ.

13. Kuchma V.R., Sedova A.S., Stepanova M.I. et al. (2020). Life and wellbeing of children and adolescents studying remotely during the epidemic of a new coronavirus infection (COVID-19). Problems of School and University Medicine and Health, 2, 4-23.

14. Korytova G.S. (2020). Autoaggressive behavior of students in the period of a pandemic of a COVID-19 infection and self-isolation. Academic Journal of West Siberia, 16, 3 (86), 26-28.

15. Shurygina V.V., Kostylev D.V., Kostyleva L.N., Reshetnik A.S., Rahmatullina E.A. (2020). Studying of regular physical activity during pandemic period. Uchenye Zapiski Universiteta Imeni P.F. Lesgafta, 11 (189), 578-581.

16. Milushkina O.Y., Popov V.I., Skoblina N.A., Markelova S.V., Sokolova N.V. (2020). The use of electronic devices by students, parents and teachers before and after the transition to distance learning. Bulletin of Russ. State Medical University, 3, 85-91.

17. Zabolotskikh N.V., Vyrodova E.Y., Dorosheva A.O. et al. (2020). Impact of distance learning on psychoemotional state in schoolchildren in Krasnodar. Kuban Scientific Medical Bulletin, 27 (6), 109-122.

18. Evaluation of the efficiency and organization of children's health improvement: computer program; Novosibirsk Research Institute of Hygiene: Certificate RU 2019665484. Application number: 2019664446. Publication date 22.11.2019. Retrieved on April 7, 2021 from http://www.niig.su/images/documents/ rezultaty-intellektualnoj-deyatelnosti/2019/Gos-regprogrammy-dlya-EVM/Gos-reg-programmy-dlyaEVMBD_2019665484.pdf.

\section{ABOUT THE AUTHORS}

Novikova Irina Igorevna - Dr. Sci. (Med.), Head, Novosibirsk Research Institute of Hygiene; Professor, Department of Hygiene and Ecology, Novosibirsk State Medical University.

Yurk Dmitriy Evgenievich - Junior Researcher, Novosibirsk Research Institute of Hygiene; Post-graduate, East-Siberian Institute of Medical and Environmental Research (Angarsk).

Mikheev Valeriy Nikolayevich - Cand. Sci. (Med.), Head, Division of Hygienic Research with the Laboratory of Physical Factors, Novosibirsk Research Institute of Hygiene.

Sorokina Aleksandra Vasilyevna - Cand. Sci. (Med.), Leading Researcher, Organizational and Methodological Division, Novosibirsk Research Institute of Hygiene. 
Сорокина Александра Васильевна - канд. мед. наук, ведущий научный сотрудник организационно-методического отдела ФБУН «Новосибирский научно-исследовательский институт гигиены».

Ивлева Галина Петровна - канд. мед. наук, ученый секретарь, заведующий организационно-методическим отделом ФБУН «Новосибирский научноисследовательский институт гигиены».

Образец цитирования : Новикова И.И., Юрк Д.Е., Михеев В.Н., Сорокина А.В., Ивлева Г.П. Особенности показателей эффективности оздоровления детей в стационарных организациях отдыха и оздоровления в период пандемии COVID-19 // Journal of Siberian Medical Sciences. 2021. № 2. C. 26-36.
Ivleva Galina Petrovna - Cand. Sci. (Med.), Scientific Secretary, Head, Organizational and Methodological Division, Novosibirsk Research Institute of Hygiene.

Citation example: Novikova I.I., Yurk D.E., Mikheev V.N., Sorokina A.V., Ivleva G.P. (2021). Features of the efficiency indicators of children's health improvement in stationary recreation and health promotion organizations during the COVID-19 pandemic. Journal of Siberian Medical Sciences, 2, 26-36. 